\title{
Prevalence of Hepatitis B and C Virus in Health Care Personnel in Ibn Sina Hospital, Rabat, Morocco
}

\author{
K. Souly*, M. Ait El Kadi, Y. Elkamouni, H. Biougnach, S. Kreit, M. Zouhdi \\ Microbiology Unit, Ibn Sina Hospital, Rabat, Morocco \\ Email: "sl.karim@hotmail.fr
}

Received 24 December 2015; accepted 15 March 2016; published 18 March 2016

Copyright (C) 2016 by authors and Scientific Research Publishing Inc.

This work is licensed under the Creative Commons Attribution International License (CC BY). http://creativecommons.org/licenses/by/4.0/

(c) (;) Open Access

\begin{abstract}
Risk of infection by hepatitis B (HBV) and C (HCV) viruses remains a permanent problem, not only for health care workers but also for patients. It is often a major public health concern in low incomes countries. The aims of this study were to determine seroprevalence of viral hepatitis $B$ (HBV) and C (HCV), frequency occurrence of blood exposure accidents (BEA) and identify key risk factors for infection among 601 health care workers of Ibn Sina Hospital in Rabat. In this study nineteen health personnel (3.16\%) were HBsAg positive and fifteen $(2.50 \%)$ were anti-HCV antibodies positive. The seropositivity to hepatitis $B$ and $C$ in the surgical department respectively was $\mathbf{4 . 2 2 \%}$ and $3.45 \%$. Nurses were the most affected by hepatitis virus infections. We noticed that HCV came first with a prevalence of $4.44 \%$. The seropositivity reached its acme within the health staff having practiced for more than 20 years, hepatitis $C$ coming first with a prevalence of $4.27 \%$. Globally, 34 health care personnel are positive for $\mathrm{HBV}$ or $\mathrm{HCV}, 32$ among them were victims at least once of blood exposure accident (BEA) while practicing. The needlestick represented $81.25 \%$ of the BEA type. Prevalence of hepatitis B and C serologic markers in health care workers in our Hospital outnumbered that of the general population. Nurses, surgery department personnel and the professional having worked for a long time were the main factors behind the high risks of infections.
\end{abstract}

\section{Keywords}

Hepatitis B Virus, Hepatitis C Virus, Blood Exposure Accident

\section{Introduction}

The risk of infection with infectious viruses from viral hepatitis B (HBV) and C (HCV) among health care per-

*Corresponding author.

How to cite this paper: Souly, K., El Kadi, M.A., Elkamouni, Y., Biougnach, H., Kreit, S. and Zouhdi, M. (2016) Prevalence of Hepatitis B and C Virus in Health Care Personnel in Ibn Sina Hospital, Rabat, Morocco. Open Journal of Medical Microbiology, 6, 17-22. http://dx.doi.org/10.4236/ojmm.2016.61004 
sonnel is a major public health issue, especially in low incomes countries. Indeed, care providers are exposed to different types of infections where one of the main germ reservoirs may be the patient. The infection can be directly transmitted by the patient or indirectly through contact with blood, body fluids or equipments [1].

In the literature, the prevalence of viral hepatitis $\mathrm{B}$ and $\mathrm{C}$ markers among health staff vary according to authors and countries. In Morocco, no prevalence study of hepatitis B and C among health personnel has been published yet.

The aims of this study were to determine seroprevalence of viral hepatitis B (HBV) and C (HCV), frequency occurrence of blood exposure accidents (BEA) and identify key risk factors for infection among health care personnel of Ibn Sina Hospital in Rabat.

\section{Material and Methods}

Ibn Sina Hospital is a university center in Rabat capital city of Morocco, where exercises 1189 health care workers. During the first trimester of 2010, the Bacteriology-Virology Laboratory of Ibn Sina Hospital in Rabat conducted a cross-sectional, descriptive and seroepidemiologic study of viral hepatitis B and C among volunteer health care workers (units agents, nurses, laboratory technicians, doctors and administrators,) working in different units. After they agreed, the persons included in this study were sampled and responded to a confidential questionnaire which aimed to identify:

- Sociodemographic data: age, sex, unit, occupational category, seniority;

- History data of blood exposure accident (BEA): their types, frequency, declaration;

- Vaccination status data against hepatitis B virus.

Search for surface antigen (HBsAg) and HCV-Ab was performed by ELISA technique (reagent: Monolisa ${ }^{\circledR}$ HBV BIO-RAD and reagent: Murex anti-HCV ABBOTT ${ }^{\circledR}$ Version 4.0 "ELISA 4th generation"). Positive results were confirmed by a second test AxSYM, Abbott Diagnostics (AxSYM HBsAg V2 and AxSYM HCV 3.0). All tests were realized according to the recommendations of the manufacturers.

\section{Results}

Among 1189 hospital employees, 601 (50.54\%) agreed to participate to this study. They were 242 (40.26\%) men and 359 (59.74\%) women; the mean age was 42.30 years (range 22 to 59). The distribution of health care personnel according to their social data is reported in Table 1. HBsAg was positive in 19 cases (3.16\%) and HCV-Ab were positive in 15 cases (2.50\%). No HBV-HCV coinfection was detected.

According to unit, the highest seroprevalence of HBsAg and HCV-Ab was seen in surgical units (respectively $4.22 \%$ and $3.45 \%$ ), where all categories were affected, except administrators group. Nurses were the occupational category the most infected with those viral infections, especially with HCV (4.44\%). However, the difference between the different occupational category was not significant ( $p>0.05)$. The mean age of $\mathrm{HBsAg}$ positive staff was 41 years with a sex ratio of $0.58(7 \mathrm{H} / 12 \mathrm{~F})$ and that of HCV-Ab positive staff was 43.5 years with a sex ratio of $0.87(7 \mathrm{H} / 8 \mathrm{~F})$. Infection with either hepatitis viruses $B$ or $C$ reached its peak after 20 years of seniority. HCV-Ab were at first rank with a rate of $4.27 \%$ and was not detected among the staff under 10 years of seniority. On the other hand, HBsAg, although reaching its maximum after 20 years of practice (3.92\%), was detected regardless the seniority, even in those having worked for less than 5 years (2.70\%) (Table 1).

During this study, among 34 hepatitis B and C seropositive health care staff, thirty-two cases (94.12\%) had at least one blood exposure accident (BEA) during their careers, much more than among staff negative for $\mathrm{HBV}$ or HCV markers (406 of 567; 71.6\%) reported a BEA ( $<<0.01$ ). Among infected staff, bites by dirty needles represented $81.25 \%$ of all type of accidents involving exposure to blood (BEA), far above cuts (12.4\%) and eye projections of blood (3.12\%) and blood on an open wound (3.12\%). Reporting of BEA by staff is very rare. Only 2 of 32 (6.25\%) declared the BEA among which a nurse who contracted HCV by needlestick contaminated with a patient infected by HCV.

\section{Discussion}

In our hospital, the prevalence of HBsAg (3.16\%) and HCV-Ab (2.50\%) is more important than the general population of Morocco (1.81\% for HBV [2] and 1.58 for HCV [2]) and blood donors ( $0.95 \%$ for HBV [2] and $0.9 \%$ to $1.2 \%$ for HCV [2]-[4]), which means that the risk of infection with viral hepatitis B or C in our hospital 
Table 1. Frequency of HBsAg and anti-HCV among health care personnel according to their socio-professional data.

\begin{tabular}{|c|c|c|c|c|c|c|c|}
\hline \multirow{2}{*}{ Risk factors } & \multirow{2}{*}{$\begin{array}{l}\text { Number of } \\
\text { personnel }\end{array}$} & \multicolumn{2}{|c|}{ HBsAg+ } & \multirow{2}{*}{$\mathrm{p}$} & \multicolumn{2}{|c|}{ Anti-HCV+ } & \multirow{2}{*}{$\mathrm{p}$} \\
\hline & & Number & $\%$ & & Number & $\%$ & \\
\hline Sex & & & & NS & & & NS \\
\hline Male & 242 & 07 & 2.90 & & 07 & 2.80 & \\
\hline Female & 359 & 12 & 3.40 & & 08 & 2.20 & \\
\hline Age groupe (years) & & & & NS & & & NS \\
\hline $20-29$ & 47 & 01 & 2.12 & & 00 & 00 & \\
\hline $30-39$ & 116 & 04 & 3.44 & & 01 & 0.86 & \\
\hline $40-49$ & 235 & 09 & 3.82 & & 05 & 2.12 & \\
\hline$>50$ & 203 & 05 & 2.46 & & 09 & 4.44 & \\
\hline Unit & & & & NS & & & NS \\
\hline Surgery & 261 & 11 & 4.22 & & 09 & 3.45 & \\
\hline ICU & 63 & 02 & 3.18 & & 00 & 00 & \\
\hline Laboratory & 95 & 03 & 3.16 & & 02 & 2.10 & \\
\hline Medicine & 114 & 02 & 1.76 & & 03 & 2.63 & \\
\hline Radiology & 46 & 01 & 2.17 & & 01 & 2.17 & \\
\hline Administratif sector & 22 & 00 & 00 & & 00 & 00 & \\
\hline Occupational category & & & & NS & & & NS \\
\hline Doctors & 147 & 04 & 2.72 & & 00 & 00 & \\
\hline Nurses & 248 & 10 & 4.03 & & 11 & 4.44 & \\
\hline Laboratory technicians & 58 & 02 & 3.45 & & 01 & 1.72 & \\
\hline Duty officers & 126 & 03 & 2.38 & & 03 & 2.38 & \\
\hline Administrators & 22 & 00 & 00 & & 00 & 00 & \\
\hline Years in occupation & & & & NS & & & NS \\
\hline$<5$ & 37 & 01 & 2.70 & & 00 & 00 & \\
\hline $5-10$ & 101 & 03 & 2.97 & & 00 & 00 & \\
\hline $10-20$ & 182 & 04 & 2.19 & & 03 & 1.64 & \\
\hline$>20$ & 281 & 11 & 3.92 & & 12 & 4.27 & \\
\hline TOTAL & 601 & 19 & 3.16 & & 15 & 2.50 & \\
\hline
\end{tabular}

NS: Not significant.

is actually increased. The comparison with the population of healthcare workers in other countries has shown that the prevalence of HBsAg found in our institution is similar to that found in Egypt [5] and Nigeria [6] and still higher than that found in Mexico [7], Turkey [8] and Japan [9], whereas it is lower than those reported in Uganda [10], Syria [11] and Singapore [12] (Table 2). This high prevalence of HBsAg could reflect a failure in the vaccination despite the vaccination campaign against hepatitis B carried out among health care personnel. Indeed, this vaccination policy that began in 1996 in Rabat does not reach its aims since only $20.1 \%$ of the staff was vaccinated in 2001 [13] and 30.2\% according to Djeriri in 2005 [14]. In our study only 34.77\% of the staff was correctly vaccinated. Indeed, during this study, many members of the nursing staff reported that the vaccination scheme was not always respected. It seems that if all 3 injections were necessarily carried out, the time between these three injections was not fully respected. Furthermore, the monitoring of the immunization response by quantification of anti-HBs was performed in only 5.32\% of vaccinees. The vaccination protocol recommended by WHO is an injection at month 0,1 and 2 with strict time limits of 30 days, since there is approximately $10 \%$ of non-or poor responders [1]. O. Laraque et al. found that post-vaccination serology (detection of anti-HBs antibodies) at the University Hospital of Rabat has been achieved in only $1.8 \%$ of vaccinees [3]. 
Table 2. HBsAg and anti-HCV seroprevalence among health care personnel in other countries.

\begin{tabular}{cccc}
\hline Study & Number of personnel & HBsAg+ & Anti-HCV+ \\
\hline Uganda 2003 [10] & 311 & $8.9 \%$ & ND \\
Syria 2001 [11] & 189 & $6 \%$ & $3 \%$ \\
Singapore 1988 [12] & 693 & $4.5 \%$. & ND \\
Egypt 1989 [5] & 765 & $3.2 \%$ & ND \\
Nigeria 2005 [6] & 325 & $3.2 \%$ & ND \\
Turquie 2004 [8] & 595 & $2.7 \%$ & $5.4 \%$ \\
Japan 1997 [9] & 1638 & $1.1 \%$ & $2.8 \%$ \\
Mexico 2006 [7] & 376 & $00 \%$ & $0.8 \%$ \\
South Africa 2002 [19] & 402 & ND & $1.8 \%$ \\
Tunisia 2005 [16] & 885 & ND & $1 \%$ \\
Germany 1991 [17] & 1018 & ND & $1.2 \%$ \\
Australia 1990 [20] & 294 & ND & $2 \%$ \\
Italy 2004 [22] & 511 & ND & $3.8 \%$ \\
Hungary 2001[15] & 477 & ND & $2.7 \%$ \\
Spain 1993 [21] & 784 & ND & $2 \%$ \\
America 1993 [18] & 1677 & ND & $1.4 \%$ \\
\hline
\end{tabular}

ND: Not determined.

The prevalence of HCV-Ab of $2.50 \%$ found among 601 health care personnel from our institution is similar to that found in Syria [11], Hungary [15] and Japan [9], but higher than that recorded in Mexico [7], Tunisia [16], Germany [17], America [18], South Africa [19], Australia [20] and Spain [21] (0.8\% to 2\%). This seroprevalence is still lower than that found in Italy [22] and Turkey [8] (Table 2). The high prevalence of HCV-Ab and HBsAg seropositivity in the surgical units joined many French studies in which the surgery units were leading with a rate of 30\% [23]-[25]. In Turkey, Kosqeroqlu, N. et al. [8] have noticed that 59.4\% of health care personnel seropositive for hepatitis $\mathrm{B}$ or $\mathrm{C}$ belong to surgical units.

The analysis of seropositivity to HBV and HCV markers according to the age showed a higher seroprevalence of HCV in our care staff after 50 years with a rate of $4.44 \%$, while for Ag HBs the highest prevalence was found between 40 and 49 years (3.82\%). HBsAg was detected in all age groups in contrast with HCV-Ab that were detected only above 30 years old and especially above 40 years old, as reported in other countries. Mihály et al. [15] found that the seroprevalence of HCV-Ab increases with age, from $0 \%$ at 21 years to a maximum reached above 50 years. Proietti L et al. [26] in southern Italy found that the seroprevalence of antibodies to HCV was the highest in an age above 45 years. The low seroprevalence of HCV-Ab in the youngest in our study reflects what is described in the same age groups from young recruits from the army $(0.35 \%)$ [27].

Nurses were the most affected by those viral infections, especially by HCV with a seroprevalence of HCV-Ab of $4.44 \%$. The significant prevalence of nursing staff found in our study corroborates the majority of the literature [8] [15] [16] [23] [28]. The population concerned is the one with an important volume of work and high risk care actions: phlebotomy, arterial, muscle and intravenous injections, sutures, wound dressings and especially recapping needles which is the action during which occurs the majority of BEA.

The seroprevalence of infection with either HBV or HBC among health care personnel reached its peak in staff with a seniority above 20 years, the HCV is in first place with a rate of $4.27 \%$ and is not among the staff who are under 10 years of occupation, unlike the HBV where the risk exists regardless of seniority, ranging from $2.70 \%$ for less than 5 years of professional occupation to 3.92\% beyond 20 years of practice. In Turkey, Kosqeroqlu, N. et al. [8] have noticed that the lowest seroprevalence of hepatitis B or C is for a period of occupation between 0 and 5 years and the highest is between 16 and 20 years.

The epidemiological profile of BEA reported in our study is similar to that already described in other studies where needlestick injuries accounted for the majority of BEA: 75\% by GERES [29], 88\% for the committee against the nosocomial infections of Hôpital Ibn-Roshd of Casablanca [13], 80\% in Paris-Nord [30], 73\% in 
Ivory Coast [31], 86.2\% in Japan [32] and 60\% in France [29]. The rate (94.12\%) suffered high BEA personnel infected in our series has corroborated the data from the literature: 93\% in Nigeria [28], 82\% in the (Nord-Pasde-Calais) France [25] and 78\% in Chile [33].

\section{Conclusions}

The prevalence of serological markers of viral hepatitis B and C in our hospital personnel exceeds that of general population. Nurses, surgery personnel, operating rooms and seniority were main risk factors for these infections.

The respect of universal health precautions by the medical staff as well as the establishing of a correct vaccination scheme against viral hepatitis $\mathrm{B}$ are urgently required to decrease the risk of infection with hepatitis $\mathrm{B}$ and $\mathrm{C}$ viruses and protect the medical staff in Morocco.

\section{References}

[1] Raffenne, L., Bodard, L. and Meudec, A. (2005) Accidents d’exposition au sang: Conduite à tenir. EMC-Médecine, 2, 291-299. http://dx.doi.org/10.1016/j.emcmed.2004.12.001

[2] Baha, W., et al. (2013) Prevalence and Risk Factors of Hepatitis B and C Virus Infections among the General Population and Blood Donors in Morocco. BMC Public Health, 13, 50.

http://www.biomedcentral.com/1471-2458/13/50 http://dx.doi.org/10.1186/1471-2458-13-50

[3] Laraqui, O., Laraqui, S., Tripodi, D., Zahraoui, M., Caubet, A., Verger, C. and Laraqui, C.H. (2008) Évaluation des connaissances, attitudes et pratiques sur les accidents d'exposition au sang en milieu de soins au Maroc. Médecine et Maladies Infectieuses, 38, 658-666. http://dx.doi.org/10.1016/j.medmal.2008.09.009

[4] Benouda, A., Boujdiya, Z., Ahid, S., Abouqal, R. and Adnaoui, M. (2008) Prévalence de l'infection par le virus de l'hépatite $\mathrm{C}$ au Maroc et évaluation des tests sérologiques de dépistage pour la prédiction de la virémie. Pathologie Biologie, 57, 368-372. http://dx.doi.org/10.1016/j.patbio.2008.07.006

[5] Goldsmith, R.S., Zakaria, S., Zakaria, M.S., Mabrouk, M.A., Hanafy, A.M., El Kaliouby, A.H. and E1-Rifae, M. (1989) Occupational Exposure to Hepatitis B Virus in Hospital Personnel in Cairo, Egypt. Acta Tropica, 46, 283-290. http://dx.doi.org/10.1016/0001-706X(89)90041-7

[6] Odusanya, O.O., Meurice, F.P. and Hoet, B. (2007) Nigerian Medical Students Are at Risk for Hepatitis B Infection. Transactions of the Royal Society of Tropical Medicine and Hygiene, 101, 465-468. http://dx.doi.org/10.1016/j.trstmh.2006.08.001

[7] Méndez-Sánchez, N., et al. (2006) Risk Factors and Prevalence of Hepatitis Virus B and C Serum Markers among Nurses at a Tertiary-Care Hospital in Mexico City, Mexico: A Descriptive Study. Annals of Hepatology, 5, 276-280.

[8] Kosqeroqlu, N., et al. (2004) Occupational Exposure to Hepatitis Infection among Turkish Nurses: Frequency of Needle Exposure, Sharps Injuries and Vaccination. Epidemiology \& Infection, 132, 27-33. http://dx.doi.org/10.1017/S0950268803001407

[9] Miajima. L., et al. (1997) Prevalence of Hepatitis C Antibodies in Health Care Personnel. Kensanshoqaku Zasshi, 91, 103-107.

[10] Braka, F., Nanyunja, M., Makumbi, I., Mbabazi, W., Kasasa, S. and Lewis, R. (2006) Hepatitis B Infection among Health Workers in Uganda: Evidence of the Need for Health Worker Protection. Vaccine, 24, 6930-6937. http://dx.doi.org/10.1016/j.vaccine.2006.08.029

[11] Othman, B.M. and Monem, F.S. (2001) Prevalence of Hepatitis C Virus Antibodies among Health Care Workers in Damascus, Syria. Saudi Medical Journal, 22, 603-605.

[12] Gob, K.T., Ghan, Y.W., Won, L.Y.M., Kong, K.H., Oon, C.J. and Gun, R. (1988) The Prevalence of Hepatitis B Virus Markers in Dental Personnel in Singapore. Transactions of the Royal Society of Tropical Mflxine and Hygiene, 82, 908-910. http://dx.doi.org/10.1016/0035-9203(88)90038-7

[13] Mrani, S., Sakhsokh, Y., Gille, Y. and Baaj, A. (2003) Épidémiologie de l’infection par les hépatites virales B et C. Cah Med, 4, 87-88.

[14] Djeriri, K., Charof, R., Laurichesse, H., Fontana, L., El Aouad, R., Merle, J.L., et al. (2005) Comportement et conditions de travail exposant au sang: Analyse des pratiques dans trois établissements de soins du Maroc. Médecine et Maladies Infectieuses, 35, 396-401. http://dx.doi.org/10.1016/j.medmal.2005.06.002

[15] Mihály, I., Telegdy, L., Ibrányi, E., Lukács, A., Rókusz, L., Bánkuti, E.E. and Dóczy, J. (2001) Prevalence, Genotype Distribution and Outcome of Hepatitis C Infections among the Employees of the Hungarian Central Hospital for Infec- 
tious Diseases. Hospital Infection, 49, 239-244. http://dx.doi.org/10.1053/jhin.2001.1087

[16] Kaabia, N., et al. (2009) Prévalence de l’hépatite virale C chez le personnel de santé au Centre tunisien. Médecine et Maladies Infectieuses, 39, 66-67. http://dx.doi.org/10.1016/j.medmal.2008.10.007

[17] Abb, J. (1991) Prevalence of Hepatitis C Virus Antibodies in Hospital Personnel and the General Population. Mikrobiologisches Institut, Krankenhaus Ludwigsburg, 53, 158-160.

[18] Polish, L.B., Long, M.J., Co, R.L., Coleman, P.J. and Alter, M.J. (1993) Risk Factors for Hepatitis C Virus Infection among Health Care Personnel in a Community Hospital. American Journal of Infection Control, 21, 196-200. http://dx.doi.org/10.1016/0196-6553(93)90031-X

[19] Vardas, E., Ross, M.H., Sharp, G., McAnerney, J. and Sim, J. (2002) Viral Hepatitis in South African Healthcare Workers at Increased Risk of Occupational Exposure to Blood-Borne Viruses. Hospital Infection, 50, 6-12.

[20] Hoffmann. H. (1990) Low Risk of Health Care Workers for Infection with Hepatitis C Virus. Infection, 18, $286-288$. http://dx.doi.org/10.1007/BF01647006

[21] Villate, J.I., Corral, J., Aguirre, C., Carrandi, B., Cobo, M., Urcelay, I. and Urberuaga, M. (1993) Hepatitis C Virus Antibodies in Hospital Personnel. Med Clin (Barc), 101, 795.

[22] Catalani, C., et al. (2004) Prevalence of HCV Infection among Health Care Workers in a Hospital in Central Italy. European Journal of Epidemiology, 19, 73-77. http://dx.doi.org/10.1023/B:EJEP.0000013250.54478.61

[23] Florentin, A., Giorgi, M. and Louet, M. (1997) Accidents de travail avec exposition au sang survenus en 1994 dans trois établissements pédiatriques de l’AP-HP. Arch Mal Prof, 58, 346-347.

[24] Abiteboul, D., Forestie Auter, A.F., Domart, M., Laville, M.F., Touche, S., Bouvet, E., et al. (2000) Accidents avec exposition au sang: Prise en charge des professionnels de santé. Concours Med (Paris), 122, 417-474.

[25] Asseray, N., Alfandari, S., Vandenbussche, C., Guery, B., Parent, K., Georges, H., et al. (1998) Analyse des pratiques et connaissances sur les accidents d'exposition au sang. Médecine et Maladies Infectieuses, 28, 612-617. http://dx.doi.org/10.1016/S0399-077X(98)80064-4

[26] Proietti, L., Origlio, A., Sandonà, P.B., Duscio, D. and Malaguarnera, M. (2003) Prevalence of HCV in Health Care Workers in Southern Italy. Clinical Therapeutics, 154, 159-162.

[27] Amine, I.L., Zouhair, S., Chegri, M. and L'kassmi, H. (2010) Seroprevalence of Anti-HCV in Patients of the Military Hospital Moulay Ismail (Meknes, Morocco): Data Analysis of the Medical Biology Laboratory (2002-2005). Bull Soc Pathol Exot, 103, 255-258. http://dx.doi.org/10.1007/s13149-010-0064-x

[28] Olobuyide, I.O. and Olawuyi, F. (1995) Self Reported Incidence of Accidental Exposures to Patients' Blood and Body Fluids by Resident Doctors in Nigeria. Journal of the Royal Society of Health, 115, 235-236, 241-243. http://dx.doi.org/10.1177/146642409511500408

[29] Clavel, T., Fleury, L., N’guyen, M.T., Abiteboul, D., Berlie, C., Bonnet, N., et al. (1997) Risques infectieux dans les laboratoires d'analyses médicales. Pré-étude en laboratoires hospitaliers. DMT, 72, 347-355.

[30] Bouvet, E. and Tarantola, A. (1998) Protection des personnels hospitaliers contre les risques d'accidents exposants au sang. Rev Prat, 48, 1558-1562.

[31] Ehui, E., Kra, O., Ouattara, I., Eholié, S., Kakou, A., Bissagnéné, E. and Kadio, A. (2007) Prise en charge des accidents d'exposition au sang au CHU de Treichville, Abidjan (Côte-d'Ivoire). Médecine et Maladies Infectieuses, 37, S251-S256. http://dx.doi.org/10.1016/j.medmal.2007.03.016

[32] Pungpapong, S., Phanuphak, P., Pungpapong, K. and Ruxrungtham, K. (1999) The Risk of Occupational HIV Exposure among Thai Health Care Workers. Southeast Asian J Trop Med Public Health, 30, 496-503.

[33] Wolff, M. and Hidalgo, S. (1992) Accidental Exposure to Health Care Workers of Blood and Body Fluids from Patients. Revista Médica de Chile, 120, 1247-1253. 